HorTSCIENCE 25(4):441-443. 1990.

\title{
Control of Salpiglossis sinuata Height with Plant Growth Regulators
}

\author{
Douglas C Needham' ${ }^{1}$ and P. Allen Hammer \\ Department of Horticulture, Purdue University, West Lafayette, IN 47907
}

Additional index words. velvet flower, painted tongue, chlormequat chloride,

daminozide, uniconazole

Abstract. Salpiglossis sinuata R. et P., a floriferous member of the Solanaceae, was studied for potential as a flowering potted plant when modified by growth retardants. Seedlings of an inbred line P-5 were covered with black cloth for an 8-hour photoperiod to permit vegetative growth to $\approx 16-\mathrm{cm}$-diameter rosettes. Plants were then exposed to an 18-hour photoperiod for the duration of study. Flowering occurred 40 days after the plants were transferred to long days. Neither spray applications of uniconazole at $10,20,40$, or $100 \mathrm{ppm}$, nor chlormequat chloride at 750,1500 , or $3000 \mathrm{ppm}$ significantly retarded plant height. Applications of daminozide, ranging in concentration from 1000 to $5000 \mathrm{ppm}$, alone and in combination with chlormequat chloride, were effective at retarding plant height; however, concomitant restriction of corolla diameter was frequently observed. Chemical names used: 2-chloro- $N, N, N$-trimethylethanaminium chloride (chlormequat chloride); butanedioic acid mono(2,2-dimethylhydrazide) (daminozide); and (E) -1-(p-chlorophenyl)-4,4-dimethyl-2-(1,2,4-triazol-1-yl) -1-penten3-01 (uniconazole).

Height of many flowering ornamental, e.g., poinsettia, hydrangea, chrysanthemum, and lily, has been controlled for floricultural pot production by the application of plant growth regulators (Larson, 1985). Although breeding has genetically reduced the height of some cultivars of these plants, growth retardants account for much of the restricted height and associated enhancement of foliage color.

Received for publication 5 Apr. 1989. Purdue Univ. Agricultural Experiment Station Journal Paper no. 11,992. We thank Terri Kirk for her assistance. Mention of trade names in this publication does not imply endorsement by the Purdue Agricultural Experiment Station of products named, nor criticism of similar ones not named. The cost of publishing this paper was defrayed in part by the payment of page charges. Under postal regulations, this paper therefore must be hereby marked advertisement solely to indicate this fact. 'Assistant Professor, Floriculture. Current address: Oklahoma State Univ., Dept. of Horticulture and Landscape Architecture, Stillwater, OK 74078-0511.
Salpiglossis express a wide variety of flower colors and patterns, e.g., red, yellow, blue, pink, and orange, with or without striping or dilution. At first flower anthesis, plants not treated with chemical growth retardants are 30 to $45 \mathrm{~cm}$ high, which is commercially unacceptable. Thus, if height could be restricted to a size appropriate for a potted plant, the marketability of salpiglossis would be enhanced and the consumers' desires for new and unusual plants could be satisfied. Three separate studies quantified the growth retardant effects of chlormequat chloride (Cycocel), daminozide (B-Nine SP), and uniconazole (Sumagic) on salpiglossis.

The highly inbred, yellow-flowering salpiglossis line P-5 (Erickson, 1982) was selected for its compact, floriferous branches and relatively short stature, in contrast to other salpiglossis inbreds with loosely arranged flowers and greater height. Seeds were sown onto a stratum of $1 \mathrm{~cm}$ of commercial peat : lite (Grace Horticultural Products' Vegetable Plug Mix) and $3 \mathrm{~cm}$ of greenhouse potting soil, composed of 1 soil : 2 sphagnum 


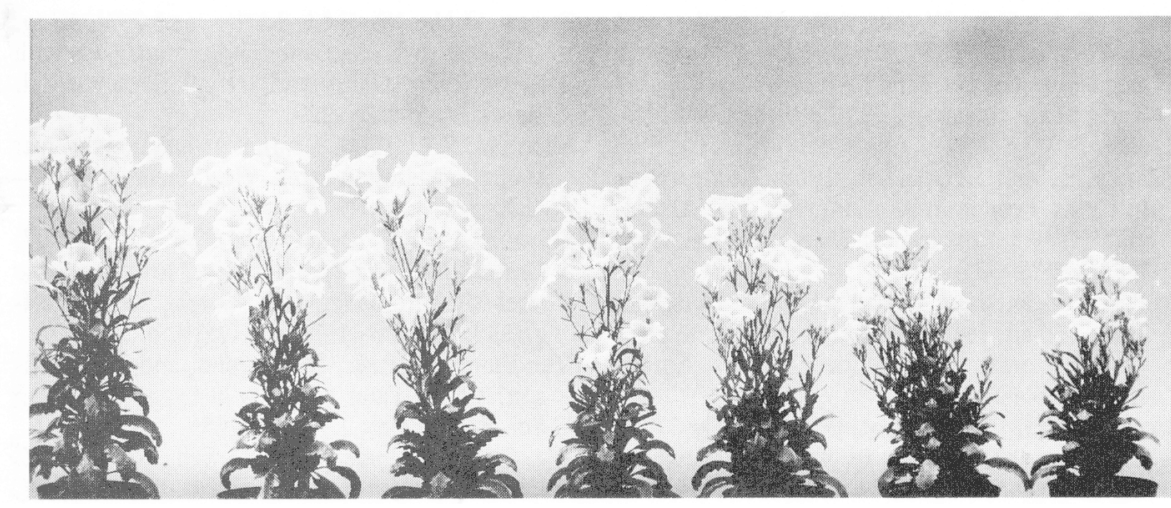

Fig. 1. Multiple applications of damiriozide at 2500 or $5000 \mathrm{ppm}$ significantly retarded height of salpiglossis. Plants represent (left to right) control, one application at 2500 , one application at 5000 , two applications at 2500 , two applications at 5000, three applications at 2500, and three applications at $5000 \mathrm{ppm}$.

Table 1. Effects of multiple applications of daminozide on plant height and corolla diameter of salpiglossis.

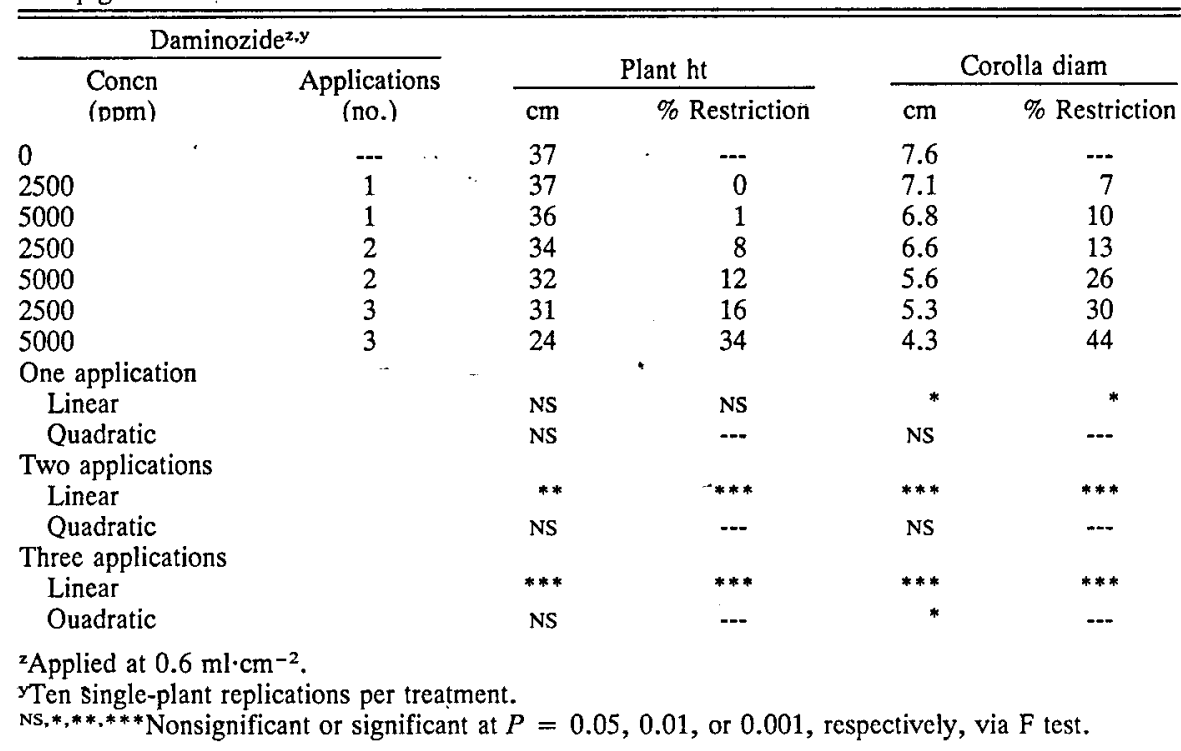

Table 2. Effects of three applications of daminozide on plant height and corolla diameter of salpiglossis.

\begin{tabular}{|c|c|c|c|c|}
\hline \multirow{3}{*}{$\begin{array}{c}\text { Daminozide } \\
\text { concn z,y } \\
(\mathrm{ppm})\end{array}$} & \multicolumn{2}{|r|}{ Plant ht } & \multicolumn{2}{|c|}{ Corolla diam } \\
\hline & & $\%$ & & 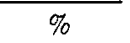 \\
\hline & $\mathrm{cm}$ & Restriction & $\mathrm{cm}$ & Restriction \\
\hline & 33 & -- & 6.5 & -.. \\
\hline & 30 & 8 & 5.8 & 10 \\
\hline 00 & 27 & 17 & 5.5 & 15 \\
\hline 000 & 26 & 20 & 5.1 & 21 \\
\hline Treatment & $* * *$ & ***** & *** & $* * *$ \\
\hline Linear & *** & $* * *$ & $* * *$ & $* * *$ \\
\hline Quadratic & NS & NS & NS & NS \\
\hline
\end{tabular}

${ }^{2}$ Applied at $0.6 \mathrm{ml} \cdot \mathrm{cm}^{-2}$.

YTwenty single-plant replications per treatment.

Ns,*,**.***Nonsignificant or significant at $P=$ $0.05,0.01$, or 0.001 , respectively, via $\mathrm{F}$ test.

peat : 2 perlite (by volume), having a $\mathrm{pH}$ of 6.2 with soluble salts of $1.64 \mathrm{dS} \cdot \mathrm{m}^{-1}$, and (all in mg.liter ${ }^{-1}$ ) $120 \mathrm{NO}_{3}, 12 \mathrm{NH}_{4}, 53 \mathrm{P}$, and $130 \mathrm{~K}$, in flats with a light dusting of plug mix over the top. Seeds were germinated under intermittent mist (on for $6 \mathrm{sec}$ every 8 min during daylight hours). The day maximum was $27 \mathrm{C}$ and the night minimum applied the morning following the first longday. Where two and three applications of a treatment were specified, they were applied in the morning 7 and 14 days after the first application, respectively.

Height of each plant was measured from the soil surface and corolla diameter was recorded when the plant's first flower dehisced pollen $(\approx 15$ weeks after sowing).

Uniconazole was applied once at 10, 20, 40 , or $100 \mathrm{ppm}$, and chlormequat chloride was applied once at 750, 1500, or $3000 \mathrm{ppm}$. Neither uniconazole nor chlormequat chloride was effective at retarding plant height. Hammer (1987) determined that $20 \mathrm{ppm}$ of uniconazole was effective at retarding plant height of Easter lilies; however, on salpiglossis it had no effect, even at the relatively high concentration of $100 \mathrm{ppm}$. In preliminary experiments, chlorosis and necrosis of leaf tissue were observed with applications of chlormequat chloride exceeding 3000 ppm.

The effects of one, two, and three applications of daminozide were examined at 2500 and $5000 \mathrm{ppm}$. Two and three applications of daminozide at $5000 \mathrm{ppm}$ and three applications at $2500 \mathrm{ppm}$ (Table 1 and Fig. 1) retarded plant height by $12 \%, 34 \%$, and $16 \%$, respectively. However, the restriction of plant height afforded by these treatments was accompanied by a restriction of corolla diameter. Three applications of daminozide at 5000 ppm resulted in a $44 \%$ restriction of corolla diameter, which was greater than that caused by the three applications at $2500 \mathrm{ppm}$ or two applications at $5000 \mathrm{ppm}$ (Table 1). Thus, it became evident that the concentration of daminozide and the number of applications needed to be coordinated so that optimal restriction of plant height would be obtained with minimal restriction of corolla diameter. An attempt to accommodate this goal was made by reducing the concentrations of daminozide while holding the number of applications constant at three (Table 2).

Form of poinsettia and other potted ornamentals has been improved with multiple applications of growth retardant at reduced concentrations when compared with fewer applications at higher concentrations (Larson, 1985). Three applications of daminozide at 1000,2000 , or $3000 \mathrm{ppm}$ retarded plant height by $8 \%, 17 \%$, or $20 \%$, respectively. Although corolla diameter also was retarded by these three treatments, the largest mean restriction was only $21 \%$, which is not commercially detrimental, with three applications at $3000 \mathrm{ppm}$.

Chlormequat chloride and daminozide have been reported to act synergistically in poinsettia (Larson and Thorne, 1987; Larson, 1986; Barrett and Nell, 1984; Shanks, 1981). In order to test for synergism in salpiglossis, a single application of each of three tankmixtures was applied. These included 1500 ppm chlormequat chloride plus 1250, 2500, or $5000 \mathrm{ppm}$ daminozide. Plant height was not different among the three treatments, and it was only $10 \%$ less than that of the control group.

Salpiglossis is native to southern Argentina and Chile (Hunziker et al., 1979) and 
grows prolifically under warm $(27 \mathrm{C} /$ day and $18 \mathrm{C} /$ night) conditions. Since the first study began in March, the second in June, and the third in July, the plants of the first study had the benefit of cooler greenhouse conditions and, thus, grew taller with dense foliage and abundant large flowers. Nontreated plants transplanted in March were $42 \mathrm{~cm}$ at first flower anthesis, those transplanted in June were $37 \mathrm{~cm}$, and those transplanted in July were $33 \mathrm{~cm}$. The increased light intensity (1000-1500 $\mu \mathrm{mol} \cdot \mathrm{s}^{-1} \cdot \mathrm{m}^{-2}$ in summer vs. $500-800 \mu \mathrm{mol} \cdot \mathrm{s}^{-1} \cdot \mathrm{m}^{-2}$ in winter) and temperature $(37 \mathrm{C} /$ day and $21 \mathrm{C} /$ night in summer vs. $27 \mathrm{C} /$ day and $18 \mathrm{C} /$ night in winter) of summer appeared to limit the vigor of the plants in the second and third studies. Therefore, one needs to adjust growth regulator applications to the requirements of the plants under the given greenhouse conditions. Less growth regulator is needed in summer than in the cooler and less light-intensive other seasons.

\section{Literature Cited}

Barrett, J.E. and T.A. Nell. 1984. Poinsettia clinic. Greenhouse Grower 2(9):46-48, 88.

Erickson, H.T., J. Steadman, C.W. Lee, and J. Janick. 1982. $\mathrm{P}_{1}-\mathrm{P}_{8}$ Diploid and tetraploid salpiglossis germplasm. HortScience 17(2):260.
Hammer, P.A. 1987. Growing ideas. GrowerTalks 51(7):98.

Hunziker, A.T. and R. Subils. 1979. Salpiglossis, Leptoglossis and Reyesia (Solanaceae): A synoptical survey. Botanical Museum Lflt. 27(12):1-43. Harvard Univ. Cambridge, Mass.

Larson, R.A. 1985. Growth regulators in floriculture, Hort. Rev. 7:399-481.

Larson, R.A. 1986. Bonzi: A new growthregulator for floricultural crops. N.C. Flower Growers Bul. 30(2):1-21.

Larson, R.A. and C.B. Thorne. 1987. Poinsettia height control in ' 86 - One giant step backward? Greenhouse Grower 5(7):66-69.

Shanks, J.B. 1981. Poinsettias-The Christmas flower. Md. Flor. 231:17-20. 